Uniform Partnership Act there are indications of its flexibility. ${ }^{103}$ The act seems primarily concerned with the establishment of an orderly system for resolving questions of rights and duties where no agreement, express or implied, exists as a basis for determination. Because of this, even a direct application of partnership law to joint ventures would leave the parties free to create, finance, operate, dissolve or terminate the venture as they see fit. Partnership law would not subject joint ventures to formal, rigid rules.

It is unfortunate for the courts to attempt construction of two systems of law when the administration of justice would be greatly facilitated by the recognition of the joint venture for what it is, a partnership. Nor is there any utility in applying partnership law "by analogy." The most rational view is that the courts should apply it directly, by command of the Uniforn Partnership Act where that law is in force, and by principle and convenience where common law governs.

George William Miller*

\title{
THE STATE BOARD OF EQUALIZATION AND LIQUOR CONTROL
}

On January 10, 1950, a liquor control officer of the California State Board of Equalization shouldered his way to the counter of a grocery store in Stockton and purchased a small bottle of Sauterne for 39 cents. A few minutes later eight other officers entered and informed the proprietor that he was under arrest for selling liquor without a license. The man in question, Charlie Hawkins, asked to see their warrant. They had none. Accounts differ as to what happened next, but in the confusion grocer Hawkins was dragged bodily from the store while customers and employees taunted the officers with cries of "Gestapo." The officers felt so unpopular that they called on the sheriff's office for a protecting convoy of deputies before returning to pick up Hawkins' stock of liquor. ${ }^{2}$

This incident was the climax of a long series of skirmishes between Mr. Hawkins and the board. It was sufficiently stark and well

103 "The rule that statutes in derogation of the common law are to be strictly construed shall have no application to this act." UPA \$ 4(1).

The act often provides that it will operate "unless the contrary intention appears," or "unless otherwise agreed," or "subject to any agreement" between the parties. Id. $\S \S 8(2), 37,18$.

* Member, second-year class.

115 Consuners Reports 220 (May 1950); Alcoholic Beverage Control Bulletin, Jan. 1950, p. 19; Sacramento Bee, Jan. 11, 1950, p. 1, col. 6 .

2 Sacramento Bee, supra note 1 . It is to be hoped for the sake of its public relations that the board will not repeat the rough tactics used in the Hawkins affair. 
publicized to focus public attention on the board's liquor control functions and to raise anew latent questions: How did the board get into the liquor control field? What are its enforcement practices? What forces produce incidents like the Hawkins affair? This comment is restricted to a general description of the board as an administrative agency and to its operations in the field of liquor control. The controlling statutes, the adjudicatory procedure, and their impact on the retail licensee will receive detailed treatment. What is perhaps the overriding problem-the peculiar dual function of the board-will have to be mentioned only in passing.

\section{Board Organization}

The board is a bifurcated agency. Its function from 1879 to 1934 was to equalize property tax rates in the various counties. In 1934, by constitutional amendment, it was given "... exclusive power to license the manufacture, importation and sale of intoxicating liquors in this state ...."3 The bulk of its business, revenue-wise, is collecting taxes on property other than liquor $;^{4}$ yet as much as half of a member's time is spent on liquor control problems.

Briefly, liquor control organization is as follows: The board consists of five members, four elected and one, the State Controller, ex officio. The elective members are elected from each of four districts for terms of four years. ${ }^{5}$ Under the board is the Liquor Control Division, headed by the Liquor Administrator. This division includes fourteen local districts. ${ }^{6}$ Each district has an administrator, a deputy, a special investigator, a supervising liquor control officer, and a number of enforcement officers.

The basic laws and rules governing the board's liquor control activities are: (1) The 1934 constitutional amendment. ${ }^{7}$ (2) The Alcoholic Beverages Control Act of 1935 (ABC Act)..$^{8}$ (3) The California Administrative Procedure Act (APA).$^{\circ}$ (4) The rules of the board..$^{10}$ (5) The Unfair Trade Practices Act.11

3 CaI. Const. Art. XX, $\$ 22$.

4 ANnual Report, State Board of Equalization, 1948-9, p. viii. The board administered $64.92 \%$ of California's taxes during the fiscal year ending June 30, 1949; revenue traceable to alcoholic beverage taxes and license fees accounted for but $3.56 \%$ of the total.

5 The district headquarters and present board members are: First, San Francisco, George R. Reilly, Chairman; Second, Oakland, James H. Quinn; Third, Roseville, Jerrold L. Seawell; Fourth, Los Angeles, William G. Bonelli. For the boundaries of the districts see map in ANNUAI REPORT, supra note 4, at iv.

6 For location of local offices and name of local administrator see cover page of any recent Alcoholic Beverage Control Bulletin.

7 Supra note 3.

8 Cal. Gen. Stats., Act 3796 (Deering 1944).

${ }^{9}$ CaI. Govt. Code $\$ \$ 11370-11528$.

10 CaI. Adm. CODE, tit. 4, c. 1.

11 Cat. Bus. \& PROF. CODE $\S \S 17000-17101$. 


\section{Board Rule Making}

The constitutional amendment gives the board authority " ... to deny or revoke any specific liquor license if it shall determine for good cause that the granting or continuance of such license would be contrary to public welfare or inorals." Section 38 of the ABC gives the board authority to make rules. Section $40-2$ of the Act and Rule 1 make rule violation grounds for revocation or suspension. Thus the rule making process and the content of the rules are of prime importance to all licensees.

Rule making is governed by the APA. ${ }^{12}$ For the licensee the important procedural points are notice of hearings, ${ }^{13}$ conduct of hearings, ${ }^{14}$ and publication of adopted rules. ${ }^{15}$ Section 11423 of the APA is followed quite closely in giving notice; particular attention is paid to publication in trade journals and mailed notices to industry representatives. A provision in the law, little used by the public, is Section 11423(b) which provides for notice to interested individuals; the board has honored such requests for notice. The hearing process, in practice is basically a matter between the board and industry representatives. Few individual retail licensees have the time or interest to cover the bulk of board rule making hearings. The hearing process is governed by the indefinite provisions of APA Section 11425 which allow hearings to be continued or postponed "... to such time and at such place as it [the board] shall determine."

The most important step to retail licensees is publication of rules after adoption. The APA provides for official notice through filing and publication of rules in the Administrative Code and Register, ${ }^{16}$ but official notice is not necessarily actual notice. Few, if any, licensees on the retail level read either the Code or the Register. Their usual sources of information are official publications of the board, trade representatives and trade journals. Under the first heading is the Alcoholic Beverage Control Bulletin ${ }^{17}$ and the board's compilation of rules. ${ }^{18}$ The monthly bulletin, however, is distributed mainly to trade representatives, and the board's compilation may be a year out of date. ${ }^{10}$ Trade representatives usually send bulletins concerning rule changes to their inembers, and trade journals publish news items on

12 While $\$ \$ 11420-11427$ are not made specifically applicable to board rule making hearings either in the APA or in $\S 38$ of the ABC, they appear to have been followed.

13 CaL. Govt. Code $\$ \S 11423,11424$.

14 Id. \& 11425 .

15 Id. $\$ \S 11380-11385$.

10 Supra note 10.

17 The monthly report of the Liquor Control Division of the board.

18 This is a reprint of the applicable part of the Administrative Code, published yearly by the board.

19 Any rules adopted, repealed, or amended in the interval between yearly printings must be found in the Administrative Code. 
changes. ${ }^{20}$ While the average retail licensee, if he makes an effort, has access to the new rules, it should be noted that the rules are lengthy, complicated and cover a wide range of subjects from record keeping to fair trade contracts, and from reports on sales to delivery dates for bock beer. Most licensees are at the retail level and this large group is usually not in close contact with trade representatives, and have little time as individuals to keep abreast of changes. ${ }^{21}$ Often the first actual notice a retail licensee receives of a board rule is when a violation is called to his attention by a liquor control officer.

There are a number of other provisions in the rule inaking chapter of the APA such as the right to petition, ${ }^{22}$ declaratory judgments, ${ }^{29}$ and the use of the "emergency" provision, which bear mention, but detailed consideration is beyond the scope of this comment. However, it should be noted that the much-abused "emergency" provisions of APA Section 11421 (b) do not seem to have been misused by the board. These provisions allow the adoption of rules without notice and hearing where the agency finds the public health and welfare make such process inpractical. Not every state agency has as good a record.

\section{Board Adjudication: The Licensing Process}

The basic media of board control is licensing power. Conditions governing licenses are set forth in the 1934 constitutional amendment, the $\mathrm{ABC}$ Act, and the board's rules. The procedures for denying, granting, revoking; or suspending licenses are set forth in the APA. ${ }^{24}$

The $\mathrm{ABC}$ Act lists some twenty-five types of licenses covering the industry from producer to retailer. ${ }^{25}$ Most licensing is at the retail level. ${ }^{26}$ Retail licenses are either "off-sale" or "on-sale", or in some cases a combination of the two. There are two types of off-sale licenses: the general license and the beer and wine license. On-sale licenses fall into three categories: general, beer and wine, and beer.

The off-sale license authorizes sale to ultimate consumers for consumption off the premises of the type of beverage covered. The off-

20 Among the trade journals are the California Retail Grocers Advocate and the Beverage Industry News.

21 A late compilation puts the total number of retail liquor licenses of all types at 43,345 . Beverage Industry News, Sept. 1, 1950, p. 1, col. 1.

22 CaL. Govt. CODE $\$ 11426$.

23 Id. \$ 11440. Parties have availed themselves of this section several times. Blatz Brewing Co. v. Collins, 88 Cal. App. 2d 438, 199 P. 2d 34 (1948). A recent non-liquor case held that failure to resort to tbis remedy did not bar a party from later availing himself of the judicial review provisions of APA \& 11523. Hollywood Turf Club v. Edwin M. Daugherty, 96 A. C. A. 858, 216 P. 2d 500 (1950).

24 CAL. Govt. CODE $§ \S 11500-11528$.

25. Supra note 8, 85 .

36 The board, ANNuAL REPORT 1948-1949, 98-99, shows a total of 2,060 manufacturer's and wholesaler's hicenses as compared to 42,420 retail licenses. 
sale general is the type commonly held by liquor stores; the off-sale beer and wine license is commonly held by grocers as an adjunct to their regular business. On-sale licenses authorize the sale of the types of liquor covered to the ultimate consumer on the premises. These licenses are held by "bars" $2 \pi$ and public eating places.

Any discussion of the board's licensing power depends on an understanding of the limitations imposed by the legislature and the board upon the number of licenses. These limitations minimize the importance of $A B C$ sections dealing with granting licenses, while making the transfer process crucial. ${ }^{23}$ Limiting the number of licenses has also raised their value; depending on the prosperity of the liquor business within a county, the cash value of a general license at this time may reach five to ten thousand dollars. ${ }^{29}$

$A B C$ Section 38f, added in 1945, limits the numbers of both on-sale and off-sale general licenses. ${ }^{30} \mathrm{On}$-sale general licenses are limited to one per thousand population in the county. However, in determining the ratio, both on-sale general and on-sale beer and wine licenses are counted. On-sale beer and wine licenses were frozen by Board Rule 61; the same one-to-a-thousand ratio is used and again the beer and wine licenses are counted with the generals. ${ }^{31}$ Similarly, off-sale general licenses are limited to one per thousand population, and the offsale beer and wine licenses are counted to determine the ratio. Here there is, in effect, a double limitation, simce the number of off-sale beer

2r What is known to the layman as a "bar" is required by the Constitution, Art. $\mathrm{XX}, \S 22$, to be a bona fide eating place. See note 76 infra.

28 "Fees for new licenses have been of little significance recently because the types of licenses for which substantial charges are prescribed have been outstanding in the maximum numbers permitted by law. License renewals yield a relatively stable income of a little under 6 million dollars a year, and transfers, which since July 1, 1945, lrave carried the same fees as new or renewed licenses of the same type, regularly produce close to a milkion dollars annually." Annual Report, State Board of Equatuzation, 1947 -8, p. 25.

$29 \mathrm{ABC} \S 7.2$ requires, as part of the recorded notice of transfer, a statement of the purchase price or consideration for the license, if there is any. The records of the Alaneda County Recorder on license transfers during 1950 revealed that out of 39 transfers chosen at random, 31 claimed "no consideration." The average of the consideration listed in the other eight cases-all involving the transfer of a general license-was approximately $\$ 7,500$. The failure to list consideration for the license is not necessarily an evasion of the law because the value of the license may be included in the sale price of the business which need not be recorded.

30 It should be noted that this limitation does not apply to the various types of "club licenses" issued under $A B C \$ \S 6.1$ and 6.11. These licenses are in effect limited by the requirements for issuance and make up less than $4 \%$ of the total on-sale generals. "Seasonal licenses," which may be held for nine months a year, are limited by Rule 61(b).

31 On-sale beer licenses, as yet unlimited, do not enter into either calculation. 
and wine licenses is as yet unlimited, and their continued issuance helps insure that further off-sale general licenses will not be issued. ${ }^{32}$

In spite of these somewhat peculiar interdependent limitations, it would seem that an increase in county population reflected in the 1950 census might make more licenses available. This may be a vain hope, for when the limitations went into effect many counties had more than the statutory ratio of licenses outstanding. ${ }^{33}$ Should the population of any county increase to the point where further general licenses are permissible, $A B C$ section $38 \mathrm{f}$ specifies the burden which an applicant must carry before a license will be granted. ${ }^{34}$

The reason most often advanced for the limitations is that "there are too many bars in California." Granting that too many bars may be detrimental to the public welfare, and create law enforcement problems, this rationale is difficult to apply to off-sale premises. A more inclusive argument is that availability of liquor increases control difficulties. Perhaps so, but the experience of prohibition should show that restricting outlets neither prevents drinking nor drinking problems. Refreshingly, one licensee lobbying group has been more candid. In a "confidential news letter" to prospective members the Retail Liquor Stores Association blandly asks, "Don't you think you've had enough competition?" 35

It would not be fair to put the entire responsibility for limiting licenses on the licensees themselves. There is constant pressure by civic groups, churches, and local authorities to restrict the issuance of

32 The latest breakdown of the number of licenses in the various categories, as reported in the Beverage Industry News, supra note 21, is as follows:

\begin{tabular}{|c|c|}
\hline 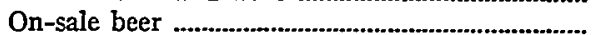 & 9,729 \\
\hline Clubs ....... & 270 \\
\hline On-sale beer and wine & 4,446 \\
\hline On-sale general ............ & 6,677 \\
\hline Off-sale general & 7,588 \\
\hline Combination on- and off-sale general.................. & 1,682 \\
\hline
\end{tabular}

33 For a listing of the total number of licenses by type and by county as of April 1, 1949, see AnNuat, Report, State Board of Equalization, table 24-A, p. 98.

34 For a recent interpretation of this section see San Diego v. State Board of Equalization, 82 Cal. App. 2d 453, 186 P. 2d 166 (1947).

35 This undated mimeographed release, apparently sent out before the 1948 elcctions, starts out as follows:

"Mr. Licensee:

"As a holder of a 'B' license you are but one of 10,090 in the State of California, selling Beer and Wine Off-Sale. Don't you think that you have enough competition?

"At the meeting of the State Board of Equilization [sic], January 8tll, a rule was adopted, freezing the On-Sale Beer and Wine ' $A$ ' licenses. This makes these licenses valuable, as no more On-Sale Beer and Wine hicenses will be issued. This Association was responsible for the freezing of the ' $C$ ' and ' $P$ ' [general] licenses and took an active part in the freezing of the ' $A$ ' licenses." 
licenses. A great many protests come to the board each year over proposed issuances or transfers. The net effect, however, is the samelicenses become valuable commodities, limited to a select few, and the oft-extolled virtues of competition are laid aside. But perhaps competition among liquor retailers is undesirable. The present California system is one of a number of alternatives. ${ }^{36}$

As stated above, the limitations have made the transfer process of paramount importance. The prospective holder of a limited license must first find some licensee who is willing to sell and then obtain board approval for the transfer. The procedure outlined by the stat- . ute is generally: (1) filing notice in the county recorder's office, (2) establishing an escrow, and (3) applying to the board for approval of the transfer. ${ }^{37}$ In the second step the purchase price of the license, or of the license and premises if they are lumped together, must be maintaind as a fund for the satisfaction of creditors of the transferor who file claims within the stipulated seven day period. According to Board Rule 60, limited licenses may be transferred from one person to another, and from one location to another, providing the new location is within the same county.

Once in possession of a license, the holder may renew it from year to year. ${ }^{38}$ However, the board has the power of revocation and suspension. ${ }^{39}$ The general grounds for these actions are set forth in $\mathrm{ABC}$ Section $40 .{ }^{40}$ The most common specific causes for revocation or suspension during the fiscal year 1948-1949, in the approximate order of frequency, were: sales to minors, operation of a "saloon," sales during prohibited hours, sales without proper license, violation of fair trade laws and sales to intoxicated persons. ${ }^{41}$ Sixty-one percent of the

36 See infra note 109.

$37 \mathrm{ABC}$ Act $\$ 7.2$; Board Rule 60. See also CaL. Crv. Code $\$ 3440$ which requires publication of notice of transfer.

$38 \mathrm{ABC}$ Act $\$ 8$.

30 The constitutional amendment mentions only revocation, but Reynolds v. State Board of Equalization, 29 Cal. 2d 137, 173 P. 2d 551 (1946), held that the power to revoke included the power to suspend.

40 (1) the continuance of the license would be contrary to public welfare and morals; (2) the violation of the $A B C$ Act, the rules, and certain other laws of the state pertaining to liquor; (3) misrepresentation of the material fact in obtaining a license; (4) being found guilty of any public offense involving moral turpitude, or of violation of certain federal laws dealing with alcololic beverages.

41 Table of board disciplinary action during fiscal year 1948-9, ANNOAL Report, State BoARd of Equalization, 1948-9, p. 23:

\begin{tabular}{|c|c|c|}
\hline Violation & $\begin{array}{l}\text { Suspensions } \\
\text { Revocations }\end{array}$ & \% of Total \\
\hline 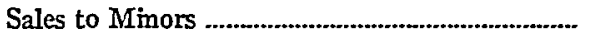 & 362 & 42 \\
\hline 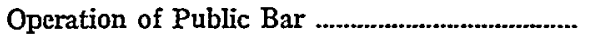 & 160 & 19 \\
\hline Violation of Fair Trade & 49 & 5 \\
\hline Sales to Intoxicated Persons & 39 & 5 \\
\hline Maintenance of Disorderly Premises.................... & 23 & 3 \\
\hline Sale or Possession without Proper License......... & 58 & 7 \\
\hline
\end{tabular}


cases fell into the first two categories. Disciplinary action in 1949 usually resulted in suspension, and the bulk of the suspensions were for fifteen days. ${ }^{42}$ It will be noted that the infractions which resulted in board action are, in general, the types most easily detected by liquor control officers on regular inspection.

Revocation or suspension under board procedure requires a hearing held in accordance with the APA. ${ }^{43}$ To illustrate the extent and importance of this phase of the board's activities, over half of all APA governed adjudicatory hearings are held under the auspices of the board's liquor control division. The Covert case ${ }^{44}$ gives this fact particular impact, for the supreme court held that board decisions were final as to matters of fact, thus removing them from the peculiar disability usually visited on the actions of other state-wide agencies. ${ }^{45}$ In effect the board is now a lower court with jurisdiction over liquor control inatters.

Since a liquor license is no longer a mere privilege revocable by the board without hearing and on its own motion, ${ }^{46}$ the general adjudicatory procedure is of special importance to the licensee. Roughly the procedural steps are: (1) filing an accusation, (2) filing a notice of defense, (3) setting a hearing date and a hearing place in the county ${ }^{4 \pi}$ where the premises or licensee is located, and (4) holding the hearing. One of four full-time hearing officers conducts the initial hearing; these hearing officers are board employees and are not supplied by the Division of Administrative Procedure. The hearing officer rules on the admission and exclusion of evidence, ${ }^{48}$ and at the conclusion of the hearing renders a "proposed" decision. ${ }^{40}$ These decisions are funneled through the office of the state liquor administrator at

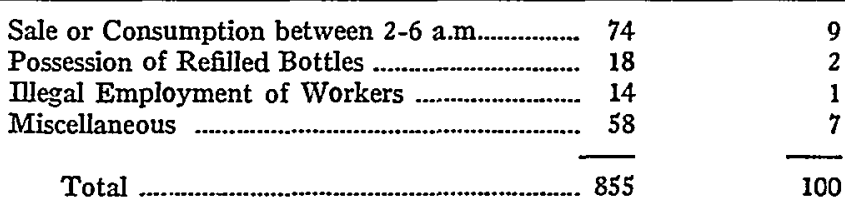

42 ABC Bulletin, May 1950, p. 20.

43 CAI. Govt. CoDE $\$ 11501$. Note that the APA does not require a hearing where no notice of defense is filed. $I d$. $\S 11506$ (b). The board, however, makes it a practice to hold hearings in all disciplinary cases. This is important because while the licensees do not return a notice of defense in $40 \%$ of the cases, they appear at the hearings in all but $4 \%$. Letter to writer from board staff, Nov. 9, 1950.

14 Covert v. State Board of Equalization, 29 Cal. 2d 125, 173 P. 2d 545 (1946).

45 For a discussion of this problem see Kleps, Certiorarified Mandamus: Coutrt Review of California Administrative Decisions 1939-1949, 2 StAN. L. REv. 285 (1950).

46 Irvine v. State Board of Equalization, 40 Cal. App. 2d 280, 104 P. 2 d 847 (1940).

47 This requirement is written into $\mathrm{ABC}$ Act $\$ 41$, along with the general provision that the hearings will be conducted in accordance with c.5 of the APA.

48 Cad. Govr. Code $\$ 11512$ (b).

${ }^{49} \mathrm{Id}$. $\S 11517$ (b). 
Sacramento who may recommend adoption, rejection, or alteration. Finally the decisions are considered by the board which may either adopt them in toto, submit the case for rehearing, or decide the case on the record. ${ }^{50}$ Decisions of the board become effective within thirty days unless a reconsideration or a stay order is granted. ${ }^{51}$ Court review may follow a board decision or reconsideration,,$^{52}$ but application for reconsideration is not a prerequisite for review. ${ }^{53}$ Stay orders may be granted either by the board ${ }^{54}$ or by a court. ${ }^{55}$

\section{Adjudication: Related Problems}

The bare description of the hearing procedure set forth in the statutes merely hints at the various factors which give board hearings a unique flavor. The board possesses an awesome degree of power. The organization of the board and its elective character, plus the large amounts of money involved in the liquor industry, shape the exercise of that power. Quite naturally rumors of abuse and even open acusations, whether valid or not, flow from such a set-up. No sensational exposé can be attempted here; more pertinent is a discussion of some of the questionable legal aspects of board adjudication.

One dubious factor is the use of full-time hearing officers. This is authorized by the $\mathrm{APA}^{56}$ and is nothing new in board procedure. However, what is questionable is the use of hearing officers for other than adjudication, and their possible loss of independence.

The Tenth Bienmial Report of the Judicial Council, in discussing the full-time hearing officer provision, states flatly that while hearing officers may be given other duties such duties "... can not be connected in any way with the investigation or prosecution of cases by the agency." $" 57$ There have been examples of board hearing officers helping with the investigations of cases heard before another officer. Also some hearing officers, when puzzled by the facts of a case, have consulted with other law enforcement agencies, state and federal, to gain more information on the record of an accused licensee. Bearing in mind that the APA does not specifically prohibit these practices, ${ }^{58}$

$50 \mathrm{Id} . \S 11517$ (c).

51 Id. § 11519(a).

62 Id. § 11523 .

53 Ibid.

54 Id. § 11519.

65 Cat. Code Civ. Proc. \$ 1094.5.

56 CaI. Govr. Code § 11502.

5i Judiclat Council of Californta, 10th Brenniax Report 14, 15 (1944).

Es The term "full-time hearing officer" is not defined in APA $\$ 11502$; it is not clear from $\$ 11512$ (c) that doing investigatory work would disqualify a hearing officer. The Judicial Council, however, seems to base its ban of investigatory work on this disqualification section. The board seems careful not to allow hearing officers to do investigatory work on cases coming up before them. However, there is a question, in a practical sense, 
they seem contrary to both the theory behind the separation of functions and the interpretation of the Judicial Council. The theory of separation of functions within an agency is that such separation prevents the same official or officials from being "prosecutor," "judge" and "jury." The language of the Judicial Council seems to proscribe investigatory work by the hearing officer both in their own cases and in any other case under the jurisdiction of the agency. Beyond these legal objections is the unfortunate impression such practice can leave with the accused licensee; such a person usually likes to feel that the "judge" who hears his case is impartial and not interested in the success of the prosecution.

Another and related charge against the full-time hearing officers is that their constant association with the board results in loss of "independence." Assuming that implementation of board policy by hearing officers is an evil, there is no conclusive evidence that there has been such a loss. In any event it is impossible to say where impartiality stops and prejudiced implementation starts. Balanced against this possibility of partiality is the loss of "expertise" in dealing with liquor control problems which might result if the hearing officers were assigned to board cases by an "outside" agency, such as the Division of Administrative Procedure.

A major criticism arises from the division of liquor control into four elective districts. ${ }^{59}$ There is a considerable tendency for each board member to be concerned primarily with his own district rather than with the state as a whole. ${ }^{60}$ It follows that the board, when acting on a case, will usually defer to the judgment of the member from the district concerned. This practice might be justified, rather cynically, on the ground that board members are elective and must please their constituents. A more impressive rationalization is that the districts vary from predominantly urban to predominantly rural, ${ }^{\text {o1 }}$ and hence

where one can draw the line between "investigation" and "consultation." Consultation with outside agencies, if carried on after a hearing and not in the presence of the accused licensee, is a dubious practice.

59 See note 5 supra.

60 "Every member of the board tries to represent the people who elected him and we reserve the right to differ on matters of policy." Bonelli, quoted in the L. A. Times, Sept. 2, 1949, p. 1, col. 8. "I'm an independent member of the board elected by my constituents and I will continue to act independently following only the wishes of those who elected me." Reilly, quoted in the Sacramento Bee, Sept. 1, 1949, p. 7, col. 1.

This is not a new criticism. Culver and Thomas, State Liquor Control Administration: A Statutory ANalysis (Bureau of Public Administration, Univ. of Calif. 1940), speaking of criticism of the board in 1935 which led to a special senate investigation, say at page 14: "Much of the dissatisfaction and criticism apparently was based on the system under which the four elective members of the Board of Equalization had divided the state, each man becoming a virtual 'dictator' in the district from which lie was elected...."

61 But do they? See inap, in ANNuAL Report, op. cit. supra note 5. 
have different problems requiring the specialized knowledge of the member from that district. However rationalized, the practice may result in the board's following a member's recommendation as to a proposed decision rather than ruling on the merits. Since the APA makes no specific requirement of deference to the decision of the hearing officer, it is a simple matter to reverse him. When a particular board member disagrees with a decision rendered in his district this reversal usually follows. ${ }^{62}$ The consequences of this type of administrative log-rolling can not be ignored.

Another point of possible criticism, not peculiar to the board, is the appearance of lawyer-legislators as advocates at board hearings. ${ }^{\infty 3}$ While it is difficult, because of lack of statistics or means of getting them, to raise this assertion above the level of a rumor, reputedly the lawyer-legislator most commonly makes his appearances before the board at reconsideration hearings. This could be explained by the reasoning of the licensee, who, suddenly realizing that he has lost his case, thinks that his chances to redeem himself will be greatly enhanced if he procures an advocate with "influence." This "influence," whether it exists or not, can be deduced from the fact that there are usually a number of bills before the legislature in which the board is interested. ${ }^{64}$ As might be expected, the board has been touchy about rumored "influence" over its functions, and on at least two occasions the state liquor administrator has taken steps to scotch such talk. ${ }^{65}$ While the incidents mentioned did not, overtly at least, involve lawyerlegislators, they indicate a problem facing the board.

There is also a procedural objection to the practice by lawyerlegislators before the board. Code of Civil Procedure Section 595, adopted in 1945, requires postponement of hearings where an advocate is a member of the legislature and the legislature is in session. This mandatory postponement has resulted in considerable delay in handling liquor cases. Regardless of what might be said against this

62 This is made easier by the mechanism of having the member from the district in which the particular cases arise make the motion for disposition. This discussion should not be taken to indicate that there are wholesale reversals of proposed decisions; such reversals are definitely in the minority. Also the board achieves a fair degree of uniformity of decision and punishment by clearing proposed decisions with the state administrator's office.

63 See Comment, 38 CaLIF. L. REv. 478, n.71 (1950).

04 ABC Bulletin, Feb. 1949, p. 19 et seq., contains a digest of over eighty bills or proposed constitutional amendments introduced in January, 1949.

65 A letter from the state administrator to liquor control officers in District 3 (Roseville) states that board personnel must not recommend attorneys because "Vicious rumors sometimes spread to the effect that a board employee is recommending the employment of counsel who is on the so-called "inside." ABC Bulletin, Dec. 1948, p. 22. See letter to licensees in District 1 , who had been accused of operating a saloon, to beware of "fixers." ABC Bulletin, July 1947, p. 21. 
particular statute or the practice of lawyer-legislators before agencies, there is very little likelihood of a legislative prohibition.

\section{Law Enforcement Problems}

Board enforcement of the liquor laws is handled by the liquor control officers, who are civil service appointees with the status of peace officers. ${ }^{66}$ They operate out of the various local officers of the board. These officers make premise inspections of the various licensees, and are required to report violations of the $A B C$ Act and board rules. While ABC Section 66.5 requires local officials to diligently enforce provisions of the $A B C$ Act, board figures indicate that by far the greatest number of imfractions are reported by board agents. ${ }^{6 r}$ According to Chairman Reilly the liquor control division occasionally finds it necessary to hire part-time investigators for special jobs where secrecy is necessary. These "private eyes" are usually hired through the state admimistrator and operate with the board for short periods. They are not civil service employees.

As might be expected, rumors circulate as to corruption in the ranks of the control officers. Seldom, however, has a victim of an alleged "payoff" made a formal complaint. This might be explained by either the non-existence of graft or the fear of retaliation should the charges be dropped. ${ }^{e 8}$ Some complaints have been made against of-

66 According to $A B C \S 38(d)$ "The members of the board and the persons employed by the board for such purposes shall have all the powers of peace officers in the enforcement of the penal provisions of this act ... . CAL. PEN. CODE $\S 817$, defining peace officers, does not include board employees in its enumeration. While there are no cases on this specific point, the board apparently relies on the general rule that the codes are to be construed together and hence the creation of peace officers by the $A B C$ can be taken as an addition to Penal Code $\S 817$. See 9 Or. ATr'y. Gen. 230 (1947). One difficulty in this reasoning is that the $A B C$ section was added in 1937 and the Penal Code section was amended in 1945 without mention of board employees.

67 ANnUat Report, State Board of Equarization, 1947-8. Numher of accusations lodged against licensees during year:

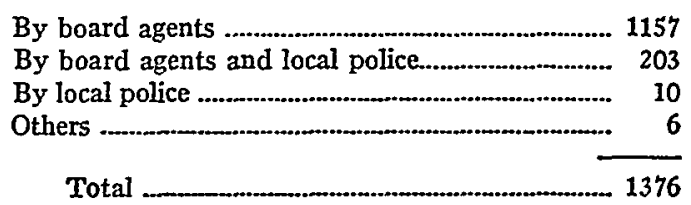

68 Retaliation can take the form of "over-inspecting." Because of the complexity of liquor control laws a licensee can easily bave violations in his store without knowing it. If the officer wants to look hard enough he can usually enter a complaint; if the officer is friendly he may make only a cursory inspection and merely remind the licensee of any noted violations. Reportedly Hawkins, after his fracas with the board agents, sold his general off-sale license because he feared further harassment and possible revocation. Another license was revoked. See text at note 86 infra. Other departments of the board seem to have taken an active interest in Hawkins' affairs; he claims to have undergone three tax audits so far this year. 
ficers, ${ }^{80}$ but there is little indication that their conduct is any less honest than that of police generally. ${ }^{70}$

It has been noted that the most common causes for license suspension or revocation are operation of a public saloon and sale of liquor to minors. ${ }^{71} \mathrm{~A}$ minor is defined as anyone under twenty-one years of age. $^{72}$ The licensee must determine the age of prospective customers at his peril ${ }^{73}$ and this peril is increased by quite widespread attempts at violation by the public. If the licensee requires strict identification of questionable customers he invites loss of trade. Enforcement of the age limit has been made more difficult by the bona fide restaurant requirement. Minors have a right to enter a public eating place but once on the premises the difficulties of preventing them from getting liquor mushroom. Some unsuccessful attempts have been made to repeal the restaurant requirement and thereby make it easier to enforce the age limit. ${ }^{\text {st }}$

Operation of a public saloon is defined as selling liquor without having food available on the premises. It is common knowledge that the primary function of many establishments is the sale of liquor, and the preparation and sale of food is purely incidental. However, under the law, the sale of hquor other than beer is proscribed "in any public saloon, public bar or public barroom within the state." "Quite recently the courts prodded the board into attempting to follow the law literally. ${ }^{76}$ The test of what distinguishes a "saloon" from a "bona fide eating place" apparently is the intent of the operator and the actual

69 S. F. Chronicle, Feb. 9, 1950, p. 17, col. 4.

Almon M. Graves, a liquor control officer who came up from Stanislaus County for the Hawkins raid, was prosecuted under CAI. PEN. CODE $\S 68$ for allegedly taking a bribe on August 27, 1949. The jury was unable to agree. The case has been reset for trial on January 9, 1951. Reportedly Graves is no longer in the board's employ. Letter to writer from District Attorney, Stanislaus County, Noveniber 22, 1950.

To The board cannot be held entirely responsible for the discipline of its officers. Outside of short suspensions, the entire disciplinary process is in the hands of the State Personnel Board. Unlike the police departments the board cannot even transfer officers, over their objection, without permission.

i1 Text at note 40 suppra.

$72 \mathrm{ABC}$ Act $\S$ ól. According to the Attorney General this blanket age requirement also applies to married women under twenty-one. ABC Bulletin, July 1948, p. 18.

${ }^{73}$ ABC Act $\$ 61.2$, however, allows the licensee to demand written evidence of age, and allows as a defense to a revocation proceeding or criminal prosecution the fact that he demanded and was shown "bona fide docunientary evidence of majority and identity ...."

$74 \mathrm{~A}$ constitutional amendment to this effect was introduced in the legislature by Senator Dillinger of Placerville. Interestingly, the senator reportedly claims that while this amendment would have lielped the average bar owner and was favored by them, it was killed by Artie Samish. Sacramento Bee, Aug. 24, 1949, p. 1, col. 2.

75. Cal. Const. Art. XX, § 22.

io Covert v. State Board of Equalization, supra note 47. Typically the "menu" in neighborhood bars consists of a few stale packaged sandwiches, hard boiled eggs and potato chips. 
operation of the business. ${ }^{\text {i7 }}$ Food sales must be "substantial" but need not make up the bulk of the revenue. However, there must be a "real offer" to sell food at the times the business is operated. ${ }^{8}$ Just what all this means is not clear. A casual survey of better known drink emporiums leaves one with the definite impression that few if any meals are served.

Convincing arguments can be made both for abolishing the bona fide restaurant requirement and for lowering the age limit. Just why installing a stove raises the moral standard of a bar is not clear. Having food on the premises may have some point, but what good is it unless someone eats it? Beyond the questionable policy involved, the test as to what meets the requirement laid down in the Covert case is a bit nebulous from the standpoint of the average licensee. It also puts a heavy burden on the board in approving installations or attempting to standardize them in a multitude of different situations. Lowering the age limit could be supported with the argument that a great many people start drinking long before they are twenty-one, and generally those who want to drink will, regardless of the law. Of course, no matter where the age limit is set the licensee would have the problem of identification. However, it seems likely that not only would identification be easier, but the pressure by the public to violate the law would be less, were the age limit eighteen rather than twenty-one.

The law enforcement task of the board is increased by California's mandatory fair trade laws. ${ }^{79}$ Over and above the complicated administration necessary to oversee the distribution, sale and consumption of liquor, the board must also police the price at which it is sold. Fair trade is a broad field in itself. This comment can consider only that portion of the law which affects the retail licensee. In passing it should be noted that a mandatory price fixing law ("fair trade") has been termed a device for using taxpayer money to maintain a relatively high price on the goods the taxpayer buys. ${ }^{80}$

77 Hammond v. McDonald, 49 Cal. App. 2d 671, 122 P. 2d 332 (1942).

78 Covert v. State Board of Equalization, supra note 44.

79 The board reports an added work load due to the 1949 "wine act" extending mandatory fair trade to the wine industry. ANNUAC REPORT, 1948-9, p. 24.

so Mandatory price fixing must be distinguished from voluntary price fixing. Under the former all goods of the specified type must be sold according to prices stipulated by the brand owner; further, violations are policed by the state rather than by private suit.

In invalidating a mandatory price fixing statute, the Florida court said: "The Act upon its face is not one designed to effect the public health, safety or welfare, but is designed solely for the protection of the wholesale liquor dealer by allowing him to control the retail prices so that his customers may be forced to sell liquor at a substantial profit, if they can sell at that profit in competition wieh the bootlegger, and thereby make the wholesaler's collections more secure." Scarborough v. Webb's Cut Rate Drug Co., $150 \mathrm{Fla} .754,778$, 8 So. 2d 913, 922 (1942). See also Liquor Store v. Continental Distilling Corp., 40 So. $2 \mathrm{~d} 371$ (1949). Illinois, New York, and Louisiana have also held mandatory fair trade laws invalid recently. Ilinois Liquor Control Commission v، Chi- 
The basic statute dealing with liquor control pricing in California is $A B C$ Section 55.5, which is expanded by Board Rule 99. The basic price fixing device is a fair trade contract, filed with the board by the "brand owner." This.instrument stipulates the prices below which the liquor must not be sold. Section 55.6 requires that all distilled spirits sold at retail be sold pursuant to a contract, ${ }^{81}$ and provides that similar treatment of other alcoholic beverages is optional. Section 55.65, a new and elaborate statute enacted in 1949, extends mandatory price fixing to all wine but makes the fair trade price the only price.

The filing of contracts and price lists is covered by $\mathrm{ABC}$ Section 55.6; Board Rules 99(b) and 99(d) prescribe the specific process. Under Rule 99 (d) the licensee is to receive notice by mail or publication in a trade journal approximately twenty days before the price amendment is effective; five days suffices if the brand was not included within a prior fair-trade contract. Wine prices, under Section 55.65, are also filed with the board before their effective date, but notice nay be given the licensee as little as five days before the change is effective.

Contract prices present the same hazard to the licensee as board rules-a violation of a fixed price is ground for disciplinary action. However, not only is the hazard intensified by the far greater number of prices which must be followed, ${ }^{82}$ but the retail licensee has no chance, even in theory, to be heard on what the prices will be.

In contrast to mandatory price fixing in the distilled liquor and wine industries, price contracts for the sale of beer are optional. Section 38(e) of the $A B C$ Act provides that each manufacturer, importer and wholesaler of beer shall file with the board a schedule of his selling

cago's Last Liquor Store, 403 III. 578, 88 N.E. $2 \mathrm{~d} 15$ (1950); Levine v. O'Connell, 88 N. Y.S. 2d 672 (1949) ; Swegmann Bros. v. Louisiana Board of Alcoholic Beverage Control, 216 La. 148, 43 So. 2d 248 (1949). Recent discussions of the fair trade problem can be found in Notes, 11 U. of PITx. L. Rev. 562 (1950) and 45 Itr. L. Rev. 378 (1950).

The question is undecided in California. Hawkins has challenged the law as applied to him in a suit in the Superior Court at Stockton. No. 47841, Dept. No. 2. Significantly Stanley A. Weigel has filed an Amicus Curiae Brief on behalf of Hawkins in this case. Weigel represents the Northern California Pharmaceutical Association, one of the strong proponents of non-liquor fair trade in California. Weigel is of the opinion that the mandatory price fixing system used in liquor transcends the legitimate scope of fair trade laws. For a valuable discussion of the California fair trade laws see the above Amicus Curiae Brief and Comment, 28 CarIf. L. Rev. 477 (1940).

In a memorandum opinion delivered August 12, 1949, the Superior Court for the County of Los Angeles held the liquor fair trade laws invalid as applied to a non-profit cooperative association and to bona fide social clubs. The court commented: "How such a delegation of power may be declared constitutional and binding upon a retailer to the extent of having his license revoked for a violation of the price, is quite difficult to uuderstand."

81 Where there is conflict between the $\mathrm{ABC}$ Act and the Cartwright Anti-Trust law, the former controls. Nelson v. Reilly, 88 Cal. App. 2d 303, 198 P. 2d 694 (1948).

82 Recent copies of the Beverage Industry Price Book, published monthly and distributed to subscribers, contain approximately 100 closely printed pages of brands and prices. As an added service the first page gives a list of recent price changes. 
prices; these prices are supposed to be followed by the filing licensees. ${ }^{83}$ However, the retailer is not bound to any resale price unless there is also a fair trade contract. Thus, on the face of the statute the beer industry is not subject to the same rigid regulation as hard liquor and wine. A likely explanation is the present fluid condition of the beer industry; there is considerable catering to the consumer's pocketbook in an attempt to build up volume. As might be expected, there are movements afoot to correct this competitive situation. ${ }^{84} \mathrm{It}$ is quite possible that we shall soon see a restrictive board rule or amendment to the $\mathrm{ABC}$ aimed at tightening the distribution of beer.

This bare discription of price fixing is not complete without a further reference to Charlie Hawkins. Hawkins lost his license because he sold a case of beer six cents below fair trade. The case cost him $\$ 2.85$; he sold it for $\$ 3.19$ and made $34 \phi$; but since the fair trade price was $\$ 3.25$, Hawkins had violated the law. Whether the "violation" was deliberate, the result of an oversight, or merely an independent groceryman's attempt to "move" an item and attract trade, it illustrates the unhappy dilemma of the non-chain retailer who wants to make his own way. ${ }^{85}$ If he attempts to meet competition by cutting the price of fair trade items he is subject to suit, and in the case of liquor the board nay "lift" his license.

The revocation of Hawkins' off-sale beer and wine license, followed by his arrest and subsequent trial, ${ }^{86}$ raises an interesting problem of price enforcement technique. Hawkins was brought to trial in February, 1950, on charges of resisting arrest and selling liquor without

83 Reportedly there is considerable violation of these prices by the filing party. These violations can take the form of an outright sale to the retailer below the listed price or, more subtly, by use of some type of rebate. Such violations, unlike retail sales before price, are extremely difficult for the board to detect. Query: If a retailer should violate a fair trade price and face charges by the board could he use an illegal "kickback" or rebate by a filing licensee as a defense?

84 A petition was submitted to the board, pursuant to APA $\$ 11426$, by the Northern and Southern California Brewer Distributors' Associations for the adoption of proposed rule 105 prohibiting special prices for special customers; the rule failed to pass by vote of 2-2. ABC Bulletin, June 1950, p. 18. The Federal Trade Counmission on January 17, 1949 filed a complaint against certain western brewer's institutes, including the Cahifornia State Brewers' Institute, charging conspiracy to fix and maintain uniform beer prices.

The board has twice attempted to force out-of-state beer manufacturers and vendors to get a "certificate of compliance" (in effect a promise to comply with California liquor laws), and las been twice blocked in the courts. Blatz Brewing Co.v. Collins. 69 Cal. App. 2d 639, 160 P.2d 37 (1945) and 88 Cal. App. 2d 438, 199 P. 2d 34 (1948).

85 The problem is roughly as follows: The independent grocer, buying from general distributors, must carry a high percentage of fair-trade itens and must sell at the prices fixed; the chain, while also carrying solne of the same fair-traded items, also carries its own brands which are not distributed to the independent retailer. Being a brand owner the chain can set its own price, and by setting this price below the usual market level for the particular type of goods, can draw trade away from the independent.

86 This particular license was in his wife's name, but on the morning of the raid the liquor control officers were not interested in nice distinctions. 
a license. He was acquitted of the first count, and the jury did not agree on the second. The board's impasse here was obvious: How can you persuade a jury of consumers to convict a man for trying to give them a break?

There is a way around this difficulty which the board may use in the future. The Unfair Trade Practices Act allows sales below cost to be enjoined. ${ }^{87}$ Injunctions may be granted to "any person or trade association." The recent case of People v. Centr-O-Mart ${ }^{88}$ upheld the right of the state to apply for an injunction, in spite of the fact that the state was not among the specifically enumerated parties plaintiff in the statute. ${ }^{99}$ In cases where this statute is applicable the board can avoid the dangers of a jury trial by encouraging the local district attorney or the attorney general's office to enjoin further price violations. Then if the licensee is defiant he will be subject to contempt proceedings.

Another important facet of the enforcement problem is the board's relationship with other law enforcement agencies in the state. The workaday evils of gambling, prostitution, and narcotics are constantly in the news; since many offenders gravitate to bars, the functions of the board and the police overlap. This has led to a running exchange between the board, the police, and lately the Governor's Crime Commission as to who should do what and to whom. The argument of the police is that liquor attracts offenders, and the owner of the premises, if threatened with loss of his license, will control them. ${ }^{.0}$ The board counters that general law enforcement is outside the scope of liquor control, and that the best way to stop illegal activities is through criminal prosecution. ${ }^{81}$

87 Supra note 11.

8834 Cal. 2d 702, 214 P. 2d 378 (1950).

89 The state had previously used the injunction under the act without being questioned. People v. Black's Food Store, 16 Cal. 2d 59, 105 P.2d 361 (1940); People v. Pay Less Drug Store, $25 \mathrm{Cal} .2 \mathrm{~d} 108,153$ P.2d 9 (1944). The rationale of the court in the Centr-O-Mart case in allowing the state to apply for an injunction was that such was in line with the purpose of safeguarding the public. A further argument was based on the negative ground that the statute did not specifically deny the state's right. From the wording of the statute it would seem that the dissent had the stronger position. Beside the fact that the specific and exclusive enumeration of parties plaintiff does not include the state, the dissent points out that under the statute selling below cost is also a misdemeanor which allows the state to take criminal action. Froin this it is argued that this statute should be interpreted like the Sherman Anti-trust Act, and the civil and criminal actions kept separate. The net result of the case is that the parties interested in price fixing and the prevention of competitive price cutting now have another taxpayer supported mechanism to keep prices up.

90 Police Chief Mitchell of San Francisco has complained bitterly about license transfers being granted over police department objections, and the difficulties caused the police by an over-concentration of bars. S. F. Chromicie, April 19, 1950, p. 1, col.4.

91 S.F. Chronicle, May 13, 1950, p. 6, col. 4; ABC Bulletin, May 1950, p. 22 ; Sacramento Bee, Nov. 19, 1948, p. 6, col. 1. 
This long standing controversy was pointed up recently by a letter to the board from Warren Olney III of the Crime Commission in which he reportedly listed a number of figures in the California "underworld" who held liquor licenses or who were in some way interested in them. Olney accompanied this tabulation with a caustic comment on the apparent immunity of these individuals from board action. ${ }^{22}$ The board did not make the contents of the letter public on grounds that it was "confidential in nature." It did, however, pass a resolution ${ }^{93}$ declaring that the information supplied was indefinite and that the local authorities carried the burden of enforcing the laws against prostitution, gambling and narcotics. ${ }^{0.4}$

If these public statements indicate the actual situation, there is a basic schism between the board and some local authorities over how the responsibility of policing law violations related to the sale of liquor should be divided. Should the board take a more positive approach to these related violations it is very likely that the present disciplinary emphasis on sales to minors and operation of a public saloon would shift to what are socially more serious problems. ${ }^{95}$

Pressure Groups and Liquor Control

What control, if any, does Artie Samish have over the board? What is the influence of the various liquor lobbies? What attention does the

A recent study of the various liquor control systems on the enforcement of criminal provisions of liquor laws commented:

"Administrative enforcement through disciplinary action against licenses and permits must be provided for and it must be neither contingent nor conditioned upon criminal conviction. The sanctions provided by criminal prosecution alone have never sufficed to 'protect the safety, welfare, health, peace and inorals of the people' in connection with the operations of the alcoholic beverage business, nor have they accomplished a degree of compliance essential to the attainment of that common objectivc of control." Alcoholic Beverage Control: An Offictal Study by The Joint ComMatTTeE of the States to Study AICoholic Beverage Laws (1950).

92 ". . . in the process of our investigations it has become evident that as a general rule liquor licensees seem to have no fear that their licenses will be revoked hecause of gambling, prostitution, narcotics traffic or any other unlawful activity." S. F. Chronicle, May 13, 1950, p. 1, col. 2 ; see Sacramento Bee, May 15, 1950, editorial page, col. 1.

93 For text of resolution see ABC Bulletin, May 1950, p. 22.

94 This recurring chant of the board is buttressed at times by reference to the fact that all the money collected froin liquor licenses and liquor excise taxes in the various cities and counties is returned to those cities and counties under ABC Act $\S 37$, and that the money is therefore available for law enforcement. S.F. Chronicle, supra note 90; ABC Bulletin, July 1946, p. 23. The Annual Report of the Board for the fiscal year $1948-9$ shows that the total amount returned to local governments was $\$ 8,041,489$, an increase of $67 \%$ over the 1946-7 figure when, under the law, only $50 \%$ of the tax and license revenue was required to be returned. A recent opinion of the attorney general held that the local governinents may spend the money for general governmental purposes whether state or local in nature; this deflates any argument that local governments are required to spend such money for law enforcement. 14 Op. CAL. ATt'y Gen. 149 (1949).

${ }_{95} \mathrm{~A}$ recent board resolution may indicate a tendency in this direction. The hoard resolved that conviction for bookmaking or possession of slot machines would be grounds 
board pay to the press? Do board members accept campaign contributions, and if so how much, from whom, and what effect does this have? Answers to these questions run from black to white; documentation, if it exists, is not available to this writer. While of all the facets of board activity these are the most difficult to explore, they may be of prime importance in determining the course of liquor control in California.

Samish received nation-wide attention recently because of two articles published in Colliers magazine. ${ }^{90}$ The articles alleged that Samish exercised considerable control over the board and its members, particularly Chairman Reilly. Reilly denied this. ${ }^{87}$ Other members of the board, prodded by the Sacramento Bee, claimed that they act as free agents. ${ }^{\text {s }}$ Very little seems to have been done to prove the contrary. Samish himself has not been very informative. ${ }^{99}$ This much at least seems certain: Samish is a lobbyist of considerable repute; some of his clients are large and wealthy liquor interests; Samish has considerable money at his disposal.

The names, activities, and influence of various liquor lobbies are obscure to the outsider; perhaps these groups will be more discernible under the new lobby control law. ${ }^{100}$ Mr. Bonelli, board member from Los Angeles, has expressed concern over disruptive political influence on board activities. In 1948 he submitted a resolution to the board calling for separation of liquor and tax functions and an appointive liquor control board with staggered ten year ternis. ${ }^{101}$ The resolution was tabled. ${ }^{102}$ The next year, when Mr. Bonelli resigned as board chairman, he made a similar statement. ${ }^{103}$ At the same time he lashed

for disciplinary action and that an accusation would be filed by the state liquor administrator. ABC Bulletin, June 1950, p. 17. The recent case of Stoumen v. Reilly, 99 A. C.A. 949,222 P. 2 d 678 (1950) not only indicates board law enforceinent action beyond the restricted field of sales to minors and operation of a "saloon" but also points out that board action against offending licensees can be greatly retarded in the courts. For over a year the board lias been trying to suspend Stoumen's license for operating "a bangout for persons of homosexual tendencies." S. F. Chronicle, Oct. 11, 1950, p. 8, col. 1.

98 Velie, The Secret Boss of California, Collier's (Aug. 13, 20, 1949).

97 S. F. Chronicle, Sept. 2, 1949.

os Sacramento Bee, Aug. 19, 1949, p. 4, col. 7.

99 See report of a perfunctory one day liearing held by the Assembly Committee on Governmental Efficiency and Econonly, entitled "Investigation of Arthur H. Samish." Sept. 22, 1949.

100 Carir. Govr. Code $\$ \$ 9900$ et seq. For a detailed treatment of this new law see Comment, 38 CaIIF. L. Rev. 478 (1950).

101 For text of proposed amendment see $A B C$ Bulletin, Nov. 1948, p. 22 ; Sacramento Bee, Nov. 19, 1948, p. 32, col. 4.

102 Sacramento Bee, Dec. 17, 1948, p. 4, col. 1. The vote to table was carried 3-2 (Reilly, Quinn, Seawell for; Bonelli, Kuchel against). According to the Bee the majority termed Bonelli's resolution as "quickly prepared and embodying drastic changes involving the administration of the $\mathrm{ABC}$ Act."

103 Sacraniento Bee, Aug. 18, 1949, p. 1, col. 5. 
out at lobbyists Samish, Hoerchner, ${ }^{104}$ and Kennedy, ${ }^{105}$ claiming that they had tied the board's hands through passage of certain sections ${ }^{100}$ of the APA in 1945. The specific importance of the various statements of the outspoken Mr. Bonelli is not clear; but they indicate a serious concern with the effect of political pulling and hauling on liquor control.

Tied in with the possible influence of Samish and the other lobbyists is the question of campaign contributions. Every four years board members stand for re-election. It costs money to campaign. While board members could pay all such expenses themselves, it is probable that they do not. Senator Judah of Santa Cruz County reportedly explains the influence of Samish as being achieved primarily through campaign contributions. ${ }^{107}$ Philbrick reports a specific cases where interested parties used a promise of substantial contributions to encourage a prospective candidate to file for state senator rather than run against the incumbent board meunber. ${ }^{108}$ Samish himself, before an assembly committee in 1949, stated that around election time the industry has to get behind "good men." There is nothing startling in this; it merely points up the fact that so long as board members are elective they will have to bear the onus of possible influence through campaign contributions.

\section{Conclusion}

Even a cursory survey of liquor control in California leaves three vivid impressions: here is a wide but self-contained field of public law with a court, police, and its own high priests; here is an agency of the state of California, presumably acting in the public interest, but gradually, with the active cooperation of many liquor interests, squeezing competition from what claims to be a "free enterprise"-

104 E. R. Hoerchner was reported to be a lóbbyist for the California State Brewers' Institute along with Samish. Ibid.

105 Anthony $J$. Kennedy is said to be the lobbyist for the California Association of Dispensing Opticians, the Cahifornia State Dental Association, and the California Legislative Council of Professional Engineers. Ibid.

106 Bonelli Lays Double Cross to Liquor Men, Sacramento Bec, Aug. 19, 1949, p. 4, col. 6. Just what sections of the APA Bonelli had in mind is not clear.

107 Sacramento Bee, Aug. 10, 1949, p. 4, col. 6.

103 The Report of H. R. Philbrick, submitted to the senate April 4, 1939, relates that $\$ 1000$ was placed in escrow for John F. Dondero of Berkeley, payable to him on his failure to file as a candidate for the board. Further promises were made of contributions totalhing $\$ 12,000$ to $\$ 15,000$ to finance Dondero's campaign for the senate. Dondero was apparently cooperating with the investigators at the time these offers were made. The "Philbrick Report" was submitted to the senate with a letter from Governor Olson commending it to that body's attention. Sen. Daily J., April 4, 1939, p. 1085. The next day the report was stricken on the motion of Senator Jerrold L. Seawell of Placer County. Id., April 5, p. 1104. The body of the stricken report has been printed in pamphlet form by Premier Publications, Sacranento. 
as distinguished from a "monopoly"109-system of liquor distribution; here is a pressing question as to whether taxes and liquor control should be under the same roof.

As to the first point, it behooves the practitioner who plans to deal with liquor cases to learn the rules and mores of his adopted community. The bulk of his trade will go through the established channels where a close working knowledge of the APA, the ABC Act, and the bent and status of board decisions is essential.

The second point springs from consideration of the mandatory price fixing system, enforced by the board with taxpayer's money, the continuing tendency to limit liquor licenses making the industry more secure for those who have gained admittance, and the fact that lobbying activities of the large liquor interests are not only notorious but extremely well heeled. In light of all this one can only wonder at the validity of outcries against so-called "state monopoly" systems of liquor control. The issue between state and private control might be rephrased as "Who should run the monopoly?"

The final issue of the bifurcated function of the board may be met some day in the political arena; yet this does not seem imminent. The board has not always been enamored of its dual capacity. ${ }^{110}$ Liquor control and general taxation are distinct subjects. Regardless of how competently the present union works, it is likely that separation of these incongruous functions would be an improvement. Were the tax and liquor functions separated the state would have to decide the crucial question of how to choose the members of the agency designated to control liquor. Bonelli's proposal that members be appointive with long staggered terms has appeal in that it would attempt to

109 This term refers to the system of liquor control used in a number of states whereby distribution is handled by state owned and operated liquor stores. George $M$. Stout, California State Liquor Administrator, gives a short outline of the merits and demerits of the so-called "monopoly" systen in ABC Bulletin, Oct. 1947, p. 31. Stout claims that under "monopoly" or state owned systen the average price of liquor is lower and there is more direct revenue to the state; however, he says this is off-set by a loss to the public in rents, wages, and property taxes, awkward spacing of outlets, and a tendency to pay more attention to revenue than to control.

For a history of liquor control in California prior to 1940 and for a detailed analysis and conparison of the two nrain liquor control systems, see CULver AND THOMAS, op. cit. stipra note 60 .

A recent study sponsored by the liquor administrator associations of both the monopoly and private enterprise states compares the various state liquor laws and nethods of control and arrives at a number of conclusions as to general principles. Arcororic Beverage Contror, op. cit. supra note 91.

110 "Whenever a feasible plan is devised to transfer liquor regulation to some other administrative authority, we shall be glad to be relieved of this responsibility ... the task of alcoholic beverage control is one of such magnitude as to merit the attention of those who have no other administrative duties to perforni .... Our principle interest is in tax administration." BIENNIAL REPORT, STATE BOARD OF EQUAIIZATION, 1935-6, p. 10. The above statement has not appeared in subsequent reports. 